\title{
Chronic Obstructive Pulmonary Disease in Never-Smoking Female Workers Exposed to Cotton Dust
}

\author{
Jordan Minov $^{1 *}$, Jovanka Karadzinska-Bislimovska ${ }^{1}$, Engin Tutkun ${ }^{2}$, Kristin Vasilevska ${ }^{3}$, Snezana Risteska-Kuc ${ }^{1}$, Saso \\ Stoleski ${ }^{1}$, Dragan Mijakoski ${ }^{1}$
}

${ }^{1}$ Institute for Occupational Health of Republic of Macedonia, Skopje, Republic of Macedonia; ${ }^{2}$ Ankara Occupational Diseases Hospital, Ankara, Turkey; ${ }^{3}$ Institute for Epidemiology and Biostatistics, Skopje, Republic of Macedonia

\begin{abstract}
Citation: Minov J, Karadzinska-Bislimovska J, Tutkun E, Vasilevska K, Risteska-Kuc S Stoleski S, Mijakoski D. Chronic Obstructive Pulmonary Disease in Never-Smoking Female Workers Exposed to Cotton Dust. OA Maced Med Sci. 2014 Jun 15; 2(2):320-326. http://dx.doi.org/10.3889/oamjms.2014.056

Key words: airflow limitation; bronchodilator reversibility testing; occupational exposure questionnaire; spirometry; textile industry.

"Correspondence: Jordan B. Minov, MD PhD. Department of Cardiorespiratory Functional Diagnostics, Institute for Occupational Health of R. Macedonia - WHO Collaborating Center and GA2LEN Collaborating Center, II Makedonska Brigada 43, 1000 Skopje, Republic of Macedonia. Tel: + 38922639 637, Fax: + 389 2621 428.E-mail: minovj@hotmail.com

Received: 27-Mar-2014; Revised: 30-Mar2014; Accepted: 03-Apr-2014; Online first: 13-May-2014

Copyright: () 2014 Minov et al. This is an open access article distributed under the terms of the Creative Commons Attribution License, which permits unrestricted use, distribution, and reproduction in any medium, provided the original author and source are credited.

Competing Interests: The authors have declared that no competing interests exist.
\end{abstract}

\begin{abstract}
AIM: Textile workers in their work environment are exposed to airborne particulate from natural and synthetic origin. In the present study we aimed at assessment of prevalence and characterstics of COPD in never-smoking female workers employed at cotton weaving sector in textile manufacture.

MATERIAL AND METHODS: In order to assess chronic prevalence and characteristics of chronic obstructive pulmonary disease (COPD) in textile industry we performed a cross-sectional study including 47 never-smoking female cotton workers (aged 36 to 56 years) and an equal number of never-smoking female office workers studied as a control. Evaluation of examined subjects consisted of completion of a questionnaire, baseline spirometry, and bronchodilator reversibility testing.

RESULTS: We found higher prevalence of respiratory symptoms in cotton workers with significant difference for phlegm and dyspnea. Majority of the chronic respiratory symptoms in cotton workers were work-related. With exception of the mean value of forced vital capacity (FVC), the mean values of all other measured spirometric parameters in cotton workers were significantly lower than in office workers. The prevalence of COPD was significantly higher in cotton workers than in office workers $(11.4 \%$ vs. $2.3 \%, P=0,027)$. COPD in cotton workers was significantly associated with age higher than 45 years and with duration of exposure longer than 20 years.
\end{abstract}

CONCLUSION: Our findings support data about relationship between occupational exposure to organic dust in textile workers and persistent airflow limitation.

\section{Introduction}

Despite the cigarette smoking is the most commonly encountered and the best-studied risk factor for chronic obstructive pulmonary disease (COPD), there is consistent evidence from epidemiologic studies that never-smokers can also develop chronic airflow limitation [1, 2]. Occupational exposures, including organic and inorganic dusts, chemical agents and fumes, are considered as an underappreciated risk factor for COPD [3, 4].

According to the results from the Third Health and Nutrition Examination Survey (NHANES III), the estimated COPD fraction attributable to work was
$19.2 \%$ overall, and $31.1 \%$ among never-smokers (5). In addition, the American Thoracic Society (ATS) statement indicated that workplace exposures account for $10-20 \%$ of either symptoms or functional impairment consistent with COPD [6].

The effect of workplace exposures on respiratory health was investigated in several studies. According to results of the Zutphen Study, the increased risks of chronic nonspecific lung disease (which includes asthma) was found in a number of occupations, and the relative risk ranged from 1.58 for farmers, 1.72 for workers in wood and paper manufacture, 2.29 for construction workers to 2.37 in textile workers and tailors [7]. Textile workers in their 
work environment are exposed to a number of airborne particulate from natural and synthetic fibrous materials [8]. The dust present in the air during handling or processing of cotton is named as a cotton dust. This dust is a complex mixture of components including cotton fibers, ground-up plant matters, bacterial, fungi soil, and pesticides, i.e. contaminants accumulated during the growing, harvesting, and subsequent processing or during storage periods [9]. There is an evidence that endotoxin from the outer cell wall of the Gram-negative bacteria contained in the cotton dust is a major causative agent in the adverse pulmonary effects in cotton workers [10]. Exposure to cotton dust and endotoxin is implicated in etiology of a number respiratory diseases, including byssinosis, chronic bronchitis (CB) and COPD [11]. On the other side, some studies indicated a possible protective effect of endotoxin on the risk of atopic sensitization [12].

In the present study we aimed at assessment of prevalence and characterstics of COPD in neversmoking female workers employed at cotton weaving sector in textile manufacture.

\section{Materials and Methods}

\section{Study design and setting}

A cross-sectional study was carried out in the Department of Cardiorespiratory Functional Diagnostics at the Institute for Occupational Health of R. Macedonia, Skopje - WHO Collaborating Center for Occupational Health and GA ${ }^{2} L E N$ Collaborating Center in the period January-September 2013. Prevalence of chronic respiratory symptoms, mean values of spirometric parameters, and prevalence of COPD was compared between a group of neversmoking female cotton workers and a group of neversmoking female office workers.

The study protocol was approved by the ethics committee of the institution and each subject gave an informed consent before entering the study.

\section{Subjects}

We examined 44 female textile workers aged 36 to 56 years, employed in a weaving manufacture producing cotton clothing with duration of employment 14 to 26 years. They worked in two work shifts lasting 8 hours in a large working area. Their working task included automatic spinning, weaving and packaging. The ring-spinning method was used to convert the prepared cotton roving into workable yarn. In addition, the clothing was formed by interlacing of two distinct sets of yarns at right angles. The process control provided keeping of the exposures at the permissible levels. The protective equipment during the working included protective clothing, gloves, and masks (i.e., disposable non-woven dust masks without valve). All examined cotton workers were never-smokers, i.e. non-smokers who have never smoked at all, or have never been daily smokers and have smoked less than 100 cigarettes in their lifetime $[13,14]$.

In addition, an equal group of never-smoking female office (administrative) workers matched to the cotton spinners by age was studied as a control.

In either group there were no subjects with chronic respiratory disease diagnosed by physician (i.e. asthma, COPD, bronchiectasis, etc.), neither subject treated with bronchodilators and/or corticosteroids. In either group also there were no subjects in whom spirometry or bronchodilator reversibility testing was contraindicated $[15,16]$.

\section{Questionnaire}

An interviewer-led questionnaire was completed by all study subjects. The questionnaire included questions on work history (e.g., chronological list of jobs; description of job activities at the actual workplace; type, extent and duration of exposure; and use of protective equipment), respiratory symptoms in the last 12 months and their relatedness to the workplace, family history of COPD and CB (taking into account the first-degree relatives), environmental exposure to tobacco smoke (ETS), accompanying disease, and medication use.

Respiratory symptoms in the last 12 months (cough, phlegm, dyspnea, wheezing, and chest tightness) were documented using the European Community for Coal and Steel questionnaire (ECCS87), and the European Community Respiratory Health Survey (ECRHS) questionnaire [17, 18]. The workrelatedness of the respiratory symptoms was defined as more than usual cough, phlegm, dyspnea, wheezing, and chest tightness during daily work [19].

ETS or passive smoking or second-hand smoking was defined as an exposure to tobacco combustion products from smoking by others (at home, workplace, etc.), i.e. as a presence of at least one smoker in the household and/or in the workplace $[20,21]$. In addition, passive smokers were divided in two groups regarding the number of hours per day they were exposed to ETS (less or more than four hours per day).

\section{Baseline spirometry}

The baseline spirometry, including measures of forced vital capacity (FVC), $\mathrm{FEV}_{1}, \mathrm{FEV}_{1} / \mathrm{FVC}$, and maximal expiratory flow at $50 \%, 25 \%$, and $25-75 \%$ of FVC (MEF ${ }_{50}, \mathrm{MEF}_{25}$, and $\mathrm{MEF}_{25-75}$, respectively), was performed in all subjects using spirometer Ganshorn SanoScope LF8 (Ganshorn Medizin Electronic GmbH, Germany) with recording the best result from three measurements the values of $\mathrm{FEV}_{1}$ of which were within $5 \%$ of each other. The results of spirometry 
were expressed as percentages of the predicted values according to the actual recommendations of European Repsiratory Society (ERS) and American Thoracic Society (ATS) $[15,16]$.

\section{Bronchodilator reversibility testing}

Bronchial reversibility testing was performed according to the actual GOLD spirometry guide (15). Spirometric measurements were performed before and 20 minutes after administration of $400 \mu \mathrm{g}$ salbutamol by metered dose inhaler through spacer. Fixed airflow narrowing characteristic for COPD was considered if post-bronchodilator $\mathrm{FEV}_{1} / \mathrm{FVC}$ remained less than 0.70 . The degree of $\mathrm{FEV}_{1}$ reversibility was expressed as \% $\mathrm{FEV}_{1}$ reversibility ([postbronchodilator $\mathrm{FEV}_{1}$ - pre-bronchodilator $\mathrm{FEV}_{1}$ ] / prebronchodilator $F V_{1} \times$ 100). Significant $F E V_{1}$ improvement (a change more than $12 \%$ and more than $200 \mathrm{~mL}$ ) in the presence of fixed airflow limitation did not negate a diagnosis of COPD.

\section{COPD diagnosis}

The diagnosis of COPD was established according to the actual GOLD recommendations [22], i.e., COPD was considered by the presence of a postbronchodilator $\mathrm{FEV}_{1} / \mathrm{FVC}$ less than 0.70 suggesting persistent airflow limitation in the subjects who had dyspnea, chronic cough or sputum production, and a history of exposure to risk factors for the disease (tobacco smoke, smoke from home cooking and heating fuels, and/or occupational dusts and chemicals).

\section{Statistical analysis}

Continuous variables were expressed as mean values with standard deviation (SD), and the nominal variables as numbers and percentages. Analyses of the data involved testing the differences in prevalence, comparison of the means, and testing the association between COPD and studied variables. Chi-square test (or Fisher's exact test where appropriate) was used for testing difference in the prevalence. Comparison of spirometric measurements was performed by independent-samples $T$-test. Chisquare test was used for testing association between COPD and studied variables. A $P$-value less than 0.05 was considered as statistically significant. Statistical analysis was performed using the Statistical Package for the Social Sciences (SPSS) version 11.0 for Windows.

\section{Results}

Demographic characteristics of the study subjects were similar in both examined groups (Table 1).
Table 1: Demographics of the study subjects.

\begin{tabular}{|c|c|c|}
\hline Variable & $\begin{array}{c}\text { Cotton workers } \\
(\mathrm{n}=44)\end{array}$ & $\begin{array}{c}\text { Office workers } \\
(\mathrm{n}=44)\end{array}$ \\
\hline Age (years) & $44.3 \pm 5.2$ & $45.7 \pm 4.7$ \\
\hline Less than 45 years & $20(45.4 \%)$ & $19(43.2 \%)$ \\
\hline More than 45 years & $24(54.6 \%)$ & $25(56.8 \%)$ \\
\hline $\mathrm{BMI}\left(\mathrm{kg} / \mathrm{m}^{2}\right)$ & $25.8 \pm 2.9$ & $26.3 \pm 3.7$ \\
\hline BMI less than 25 & $19(43.2 \%)$ & $18(40.9 \%)$ \\
\hline BMI more than 25 & $25(56.8 \%)$ & $26(59.1 \%)$ \\
\hline Duration of employment (years) & $19.4 \pm 5.1$ & $21.7 \pm 4.6$ \\
\hline $\begin{array}{l}\text { Duration of employment } \\
\text { less than } 20 \text { years }\end{array}$ & $23(52.3 \%)$ & $24(54.6 \%)$ \\
\hline $\begin{array}{l}\text { Duration of employment } \\
\text { more than } 20 \text { years }\end{array}$ & $21(47.7 \%)$ & $20(45.4 \%)$ \\
\hline Former employment in dusty trades & $9(20.5 \%)$ & I \\
\hline Family history of COPD or $\mathrm{CB}$ & $5(11.4 \%)$ & $7(15.9 \%)$ \\
\hline Environmental ETS & & $16(36.4 \%)$ \\
\hline Exposed less than 4 hours & $21(47.7 \%)$ & $10(22.7 \%)$ \\
\hline Exposed more than 4 hours & $\begin{array}{l}14(31.8 \%) \\
7(15.9 \%)\end{array}$ & $6(13.6 \%)$ \\
\hline \multicolumn{3}{|l|}{ Accompanying diseases } \\
\hline Arterial hypertension & $6(13.6 \%)$ & $8(18.2 \%)$ \\
\hline Diabetes mellitus type 2 & & $3(6.8 \%)$ \\
\hline Peptic ulcer & $\begin{array}{l}3(1.8 \%) \\
4(9.1 \%)\end{array}$ & $3(6.8 \%)$ \\
\hline
\end{tabular}

Numerical data are expressed as mean value with standard deviation; frequencies as number and percentage of study subjects with certain variable. BMI: body mass index; kg: kilogram; m: meter; COPD: chronic obstructive pulmonary disease; CB: chronic bronchitis; ETS: exposure to tobacco smoke.

Prevalence of overall respiratory symptoms in the last 12 months was higher in cotton workers but statistical significance was not reached. Regarding particular chronic respiratory symptoms, we registered significantly higher prevalence of phlegm and dyspnea in cotton workers (Table 2).

Table 2: Prevalence of respiratory symptoms in the last 12 months in the study subjects.

\begin{tabular}{lccc}
\hline $\begin{array}{l}\text { Respiratory symptoms } \\
\text { in the last 12 months }\end{array}$ & $\begin{array}{c}\text { Cotton workers } \\
(\mathrm{n}=44)\end{array}$ & $\begin{array}{c}\text { Office workers } \\
(\mathrm{n}=44)\end{array}$ & $\begin{array}{c}P \text { - } \\
\text { value }^{\star}\end{array}$ \\
\hline Overall respiratory symptoms & $19(43.2 \%)$ & $12(27.3 \%)$ & 0.117 \\
in the last 12 months & $15(31.8 \%)$ & $10(22.7 \%)$ & 0.093 \\
Cough & $8(18.2 \%)$ & $2(4.5 \%)$ & 0.021 \\
Phlegm & $8(18.2 \%)$ & $3(6.8 \%)$ & 0.041 \\
Dyspnea & $7(15.9 \%)$ & $5(11.4 \%)$ & 0.108 \\
Wheezing & $6(13.6 \%)$ & $5(11.4 \%)$ & 0.254 \\
Chest tightness & & & \\
\hline
\end{tabular}
variable. ${ }^{*}$ Tested by Chi-square test (or Fisher's exact test where appropriate).

The majority of respiratory symptoms in the last 12 months in cotton workers were work-related symptoms (78.9\%). The highest relatedness with workplace in cotton spinners was reported for cough $(73.3 \%)$ and phlegm (87.5\%). Work relatedness of the symptoms was reported by $12.0 \%$ of the office workers with respiratory symptoms, i.e. by three office workers with cough.

Table 3: Mean baseline values of spirometric parameters in the study subjects.

\begin{tabular}{lccc}
\hline $\begin{array}{l}\text { Spirometric } \\
\text { parameter }\end{array}$ & $\begin{array}{c}\text { Cotton workers } \\
(\mathrm{n}=44)\end{array}$ & $\begin{array}{c}\text { Office workers } \\
(\mathrm{n}=44)\end{array}$ & $P$-value* \\
\hline FVC $(\%$ pred) & $96.7 \pm 11.8$ & $98.6 \pm 8.7$ & 0.091 \\
$\mathrm{FEV}_{1}$ (\%pred) & $84.2 \pm 7.9$ & $89.1 \pm 11.2$ & 0.022 \\
$\mathrm{FEV}_{1} / \mathrm{FVC}$ & $0.80 \pm 0.07$ & $0.84 \pm 0.05$ & 0.038 \\
$\mathrm{MEF}_{50}$ (\%pred) & $64.6 \pm 11.8$ & $73.1 \pm 10.4$ & 0.006 \\
$\mathrm{MEF}_{25}$ (\%pred) & $52.1 \pm 12.2$ & $67.2 \pm 11.7$ & 0.000 \\
$\mathrm{MEF}_{25-75}$ (\%pred) & $63.7 \pm 14.9$ & $75.1 \pm 16.2$ & 0.000 \\
\hline
\end{tabular}

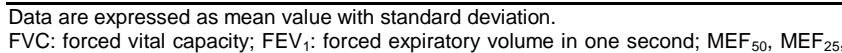
FVC: forced vital capacity; $\mathrm{FEV}_{1}$ : forced expiratory volume in one second; $\mathrm{MEF}_{50}, \mathrm{MEF}_{25}$,
$\mathrm{MEF}_{25-75}$ : maximal expiratory flow at $50 \%, 25 \%$ and $25-75 \%$ of $\mathrm{FVC}$, respectively; \% pred: $\mathrm{MEF}_{25-75}$ : maximal expiratory flow at $50 \%, 25 \%$ and $25-75 \%$ of $\mathrm{FVC}$, respectively; \% pred:
$\%$ of predicted value. ${ }^{*}$ Compared by Independent-samples $T$-test. 
With exception of the mean baseline value of FVC, the mean baseline values of all other spirometric parameters were significantly lower in cotton workers (Table 3).

The mean post-bronchodilator values of all spirometric parameters except of the FVC were also significantly lower in cotton workers (Table 4). The mean $\mathrm{FEV}_{1}$ reversibility (\%FEV ${ }_{1}$ reversibility) was significantly higher in cotton workers $(10.3 \%$ vs. $3.8 \%$, $P=0.017$; Independent-samples $T$-test).

Table 4: Mean post-bronchodilator values of spirometric parameters in the study subjects.

\begin{tabular}{|c|c|c|c|}
\hline $\begin{array}{l}\text { Spirometric } \\
\text { parameter }\end{array}$ & $\begin{array}{c}\text { Cotton workers } \\
(n=44)\end{array}$ & $\begin{array}{c}\text { Office workers } \\
(\mathrm{n}=44)\end{array}$ & $P$-value \\
\hline FVC (\%pred) & $96.3 \pm 9.4$ & $98.2 \pm 12.1$ & 0.094 \\
\hline $\mathrm{FEV}_{1}$ (\%pred) & $86.5 \pm 10.1$ & $92.8 \pm 13.2$ & 0.016 \\
\hline $\mathrm{FEV}_{1} / \mathrm{FVC}$ & $0.84 \pm 0.09$ & $0.89 \pm 0.11$ & 0.022 \\
\hline $\mathrm{MEF}_{50}$ (\%pred) & $73.1 \pm 11.2$ & $83.9 \pm 11.6$ & 0.003 \\
\hline $\mathrm{MEF}_{25}$ (\%pred) & $61.2 \pm 15.7$ & $78.7 \pm 12.9$ & 0.000 \\
\hline $\mathrm{MEF}_{25-75}$ (\%pred) & $71.4 \pm 15.7$ & $84.7 \pm 13.3$ & 0.000 \\
\hline
\end{tabular}

Data are expressed as mean value with standard deviation. FVC: forced vital capacity; $\mathrm{FEV}_{1}$ : forced expiratory volume in one second; $\mathrm{MEF}_{50}, \mathrm{MEF}_{25}, \mathrm{MEF}_{25-75}$ : maximal expiratory flow at $50 \%, 25 \%$ and $25-75 \%$ of FVC, respectively; \% pred.: \% of predicted value. ${ }^{*}$ Compared by Independent-samples $T$-test.

Five subjects among cotton workers and one subject among office workers met criteria for diagnosis of COPD $(11.4 \%$ vs. $2.3 \%, P=0.027$; Fisher's exact test) (Figure 1). All cotton spinners with COPD and none of the office workers with COPD reported work-relatedness of their symptoms. According to the GOLD 2010 classification of COPD severity [23], all subjects with COPD can be categorized as a mild COPD $\left(\mathrm{FEV}_{1} / \mathrm{FVC}<0.70 ; \mathrm{FEV}_{1}\right.$ $\geq 80 \%$ predicted).

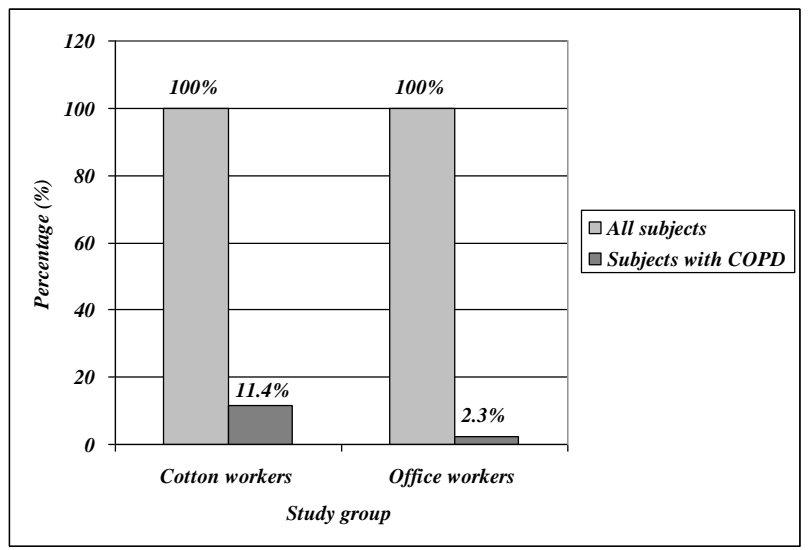

Figure 1: Prevalence of COPD in the study subjects.

COPD in cotton workers was significantly associated with age more than 45 years $(P=0.026$; Chi-square test), as well as with duration of employment more than 20 years $(P=0.014$; Chisquare test). Associations between COPD and other variables (e.g., BMI, family history of COPD or CB, and environmental ETS) were statistically nonsignificant in both bricklayers and office workers. Association between COPD and former employment in dusty trades in cotton spinners was also statistically non-significant.

\section{Discussion}

COPD is one of the leading causes of morbidity and mortality worldwide and results in an economic and social burden that is both substantial and increasing [24]. Often, the prevalence of COPD is directly related to the prevalence of cigarette smoking, although occupational, outdoor and indoor air pollution are also important COPD risk factors [25]. There is sufficient evidence that an irreversible airflow obstruction (COPD) may be caused by exposures other than tobacco smoke, and that occupational exposures, particularly to dust, are amongst such causes [26]. The widespread habit of tobacco smoking in industrial populations has delayed the recognition of other factors contributing to the disease, as it is only possible to examine the independent risks of smoking and occupational exposures when a reasonable proportion of those occupationally exposed are lifelong non-smokers. By experts' opinion, as the working population smokes less, the significance of occupational exposures causing COPD will increase [27].

In the present study we assessed the impact of specific occupational exposure in never-smoking female cotton workers on developing of COPD. A group of never smoking female office workers with similar age to cotton workers were studied as a control. The examined groups included subjects with similar demographic characteristics. In either group there was a large proportion of passive smokers that is similar to its prevalence among workers in $R$. Macedonia documented in our previous studies [28, 29] and indicate still insufficient nationwide smoking cessation activities.

It is well established that workplace exposure to certain types of organic dust can cause respiratory inflammation and thereby leads to development of chronic respiratory symptoms and ventilatory function impairment. We found higher prevalence of overall respiratory symptoms in the last 12 months among the workers exposed to cotton dust than in office workers with significant difference for phlegm and dyspnea. The majority of the respiratory symptoms among cotton workers were related to the workplace. An excess of chronic respiratory symptoms in workers exposed to organic dust is reported in many studies [30-33].

The mean values of spirometric parameters were lower in cotton workers and statistical difference was registered for all of them with exception for the mean value of FVC. This finding confirms thesis that exposure to organic dust (e.g. cotton, grain, wood, etc.) may lead to lung function impairment independently of any effect due to smoking [34]. A few longitudinal studies indicated accelerated annual decline of FEV1 independent of smoking in workers exposed to wood dust $[35,36]$, cotton dust in textile workers [37, 38], grain dust in grain handlers [39] and to organic dust, ammonia and endotoxin in swine 
production workers (40). The results of the study of Glindmeyer et al. carried out in 1991 (41) indicated that the effect of low exposures to cotton dust on lung function was seen only in smokers, while the effect in non-smoking workers was observed at higher levels of cotton dust exposure. On the other side, in the analysis of the total data within the European Community Respiratory Health Survey (ECRHS) framework, Zock et al. found no association between occupational exposure and quantitative $\mathrm{FEV}_{1}$ changes [42].

We performed bronchodilator reversibility testing in order to detect subjects with the presence of a post-bronchodilator $F_{E V} / F V C$ less than 0.70 , i.e., to establish the diagnosis of COPD. According to the actual GOLD recommendations, the postbronchodilator spirometry is required for diagnosis and assessment of severity of COPD, but the degree of reversibility of airflow limitation (e.g., $F E V_{1}$ measurements before and after administration of bronchodilator) is no recommended [22]. We found significantly higher COPD prevalence in cotton workers than in office workers that confirms the association between exposure to cotton dust and COPD development i.e. that supports the observations that cigarette smoke and some forms of organic dust contain the same pro-inflammatory agents and trigger the same effector molecule in the airways. In the case-control study aimed to ascertain the risk of COPD in male workers in different occupations with respect to office workers as a reference group, Mastrangelo et al. [43] found that age, smoking (both current and former habit), the average cigarettes number, as well as occupational factors were strong risk factors for COPD. The reported age-smoking adjusted odds ratios (ORs) for COPD ranged from 15.1 in farmers, 12.1 in foundry workers, 7.2 in cotton workers, 6.4 in welders, 6.5 in refractory brick workers, 4.7 in painters to 3.1 in construction workers. Similarly to the findings from the mentioned study, in the present study COPD in cotton workers was strongly linked to age and to duration of exposure to cotton dust.

The findings in this study are subjects to at least three limitations. First, relatively small number of the subjects in the study groups could have certain implications on the data obtained and its interpretation. Second, environmental measurements were not performed, so we could not document the effect of the type and the level of exposure on COPD. The third limitation of the study is its cross-sectional design which enables identifying associations rather than cause-and-effect relationships. In addition, as in the case of any cross-sectional study, the impact of healthy workers' effect (HWE) on the data obtained could not be excluded. The HWE is the most common selection bias in occupational studies occurring because relatively healthy individuals are likely to gain employment and to remain employed and it may partially or completely mask excess mortality and morbidity caused by harmful exposure (survivor bias). On the other side, most of the evidence of an association between occupational exposures and COPD is available in cross-sectional studies on groups of workers with specific jibs and/or exposures $[10,22,43]$. The strength of the study is the investigation of respiratory effects of occupational exposure on never-smoking workers performing specific activity within the textile manufacture.

In conclusion, in a cross-sectional study including never-smoking female cotton workers we found a higher prevalence of respiratory symptoms in the last 12 months, higher mean values of spirometric parameters, and significantly higher prevalence of COPD than in the matched female office workers. COPD in cotton workers was significantly associated with age over 45 years, as well as with duration of occupational exposure longer than 20 years. Our findings support data from other studies about relationship between occupational exposure to organic dust in textile manufacture and persistent airflow limitation and indicate the need of improvement of preventive measures in order to protect the respiratory health of exposed workers.

\section{Ethical Approval}

The Ethical Committee of the Institute of Occupational Health of R. Macedonia, Skopje - WHO Collaborating Center and GA $^{2} \mathrm{LEN}$ Collaborating Center gave approval for performing the study and publishing the results obtained (03-723/10.2013).

\section{Authors Participations}

JM participated in the study design, writing the protocol, data collection, managing the analyses of the study, and writing all versions of the manuscript. JKB participated in the study design, writing the protocol, managing the analyses of the study, as well as writing all versions of the manuscript. ET participated in the managing the analyses of the study and in the writing all versions of the manuscript. KV performed the statistical analysis and participated in the managing of the analyses of the study. SS, DM and SRK participated in the data collection and in the managing of the analyses of the study. All authors read and approved the final manuscript.

\section{References}

1. Behrendt CE. Mild and moderate-to-severe COPD in nonsmokers. Distinct demographic profiles. Chest. 2005; 128: 12391244.

2. Celli BR, Halbert RJ, Nordyke RJ, Schan B. Airway obstruction in never smokers: results from the Third National Health and Nutrition Examination Survey. Am J Med. 2005; 118: 1364-1372.

3. Matheson MC, Benke G, Raven J, Sim MR, Kromhout H, Vermeulen R, Johns DP, Walters EH, Abramson MJ. Biological dust 
exposure in the workplace is a risk factor for chronic obstructive pulmonary disease. Thorax. 2005; 60: 645-651.

4. Hnizdo E, Sullivan PA, Bang KM, Wagner G. Airflow obstruction attributable to work in industry and occupation among U.S. race/ethnic groups: a study of NHANES III data. Am J Ind Med. 2004; 46: 126-135.

5. Hnizdo E, Sullivan PA, Bang KM, Wagner G. Association between chronic obstructive pulmonary disease and employment by industry and occupation in the US population: a study of data from the Third National Health and Nutrition Examination Survey. Am J Epidemiol. 2002; 156: 738-746.

6. Balmes J, Becklake M, Blanc P, Henneberger P, Kreiss K, Mapp C, Milton D, Schwartz D, Toren K, Viegi G. American Thoracic Society Statement: Occupational contribution to the burden of airway disease. Am J Respir Crit Care Med. 2003; 167: 787-797.

7. Heederik D, Kromhout H, Burema J, Biersteker K, Kromhout D. Occupational exposure and 25-year incidence rate of nonspecific lung disease: the Zutphen Study. Int J Epidemiol. 1990; 19: 945952.

8. Oldenburg M, Latza U, Baur X. Exposure-response relationship between endotoxin exposure and lung function impairment in cotton textile workers. Int Arch Occup Environ Health. 2007; 80: 388-395.

9. Cotton Dust. Proceedings of the $10^{\text {th }}$ Cotton Dust Research Conference, 1986.

10. Paudyal P, Semple S, Niven R, Tavernier G, Ayres JG Exposure to dust and endotoxin in textile processing workers. Ann Occup Hyg. 2011; 55 (4): 403-409.

11. Hendrick DJ. Occupation and chronic obstructive pulmonary disease. Thorax. 1996; 947-955

12. Smit LA, Heederik D, Doekes G, Lammers JW, Wouters IM. Occupational endotoxin exposure reduces the risk of atopic sensitization but increases risk of bronchial hyperresponsiveness. Int Arch Allergy Immunol. 2010; 152: 151-158.

13. World Health Organization. Guidelines for controlling and monitoring the tobbaco epidemic. Geneva, WHO, 1998.

14. Leffondre K, Abrahamowicz M, Siemiatycki J, Rachet B Modelling smoking history: A comparison of different approaches. Am J Epidemiol. 2002; 156: 813-823.

\section{Spirometry Guide: 2010 Update. http://www.goldcopd.org/uploads/users/files/GOLD_Spirometry_201 o.pdf. Accessed 09.10.2013}

16. Miller MR, Hankinson J, Brusasco V, Burgos F, Casaburi R, Coates A, Crapo R, Enright P, van der Grinten CPM, Gustafsson P, Jensen R, Johnson DC, Maclntyre N, McKay R, Navajas D, Pedersen OF, Pellegrino R, Viegi G, Wanger J. Standardisation of spirometry. Eur Respir J. 2005; 26: 319-338.

17. Minette A. Questionnaire of the European Community for Coal and Steel (ECSC) on respiratory symptoms. 1987 - updating of the 1962 and 1967 questionnaires for studying chronic bronchitis and emphysema. Eur Respir J. 1989; 2:165-177.

18. European Community Respiratory Health Survey. Variations in the prevalence of respiratory symptoms, self-reported asthma attacks, and use of asthma medication in the European Respiratory Health Survey (ECRHS). Eur Respir J. 1996; 9: 687-695.

19. Meijer E, Grobbe DE, Heederik DJJ. Health surveillance for occupational chronic obstructive disease. J Occup Environ Med. 2001; 43: 444-450.

20. U.S. Department of Health and Human Services. The health consequences of smoking: chronic obstructive pulmonary disease. A report of the Surgeon General. US Department of Health and Human Services, Public Health Service, Office of the Assistant for Health, Office of Smoking and Health. DHHS Publication No. 84-50 205, 1984.

21. Janson C, Chinn S, Jarvis D, Zock JP, Toren K, Burney P, for the European Community Respiratory Health Survey. Effects of passive smoking on respiratory symptoms, bronchial responsiveness, lung function, and total serum IgE in the European Community Respiratory Health Survey: a cross-sectional study. Lancet. 2001; 358: 2103-2109.

22. Global Strategy for the Diagnosis, Management, and Prevention of Chronic Obstructive Pulmonary Disease: Updated 2013. Available at: http://www.goldcopd.org/uploads/users/files/ GOLD_Report_2013_Feb20.pdf. Accessed 09.10.2013.

23. Global Strategy for the Diagnosis, Management, and Prevention of Chronic Obstructive Pulmonary Disease: 2010 Update. Available at: $\quad h t t p: / / w w w . g o l d c o p d . o r g / G u i d e l i n e s / g u i d e l i n e-2010-g o l d-$ report.html. Accessed 09.10.2013.

24. Lopez AD, Shibuya K, Rao C, Mathers CD, Hansell AL, Held LS, Schmid V, Buist S. Chronic obstructive pulmonary disease: current burden and future perspectives. Eur Respir J. 2006; 27 397-412.

25. Salvi SS, Barnes PJ. Chronic obstructive pulmonary disease in non-smokers. Lancet. 2009; 374: 733-743.

26. Trupin L, Earnest G, San Pedro M, Balmes JR, Eisner MD, Yelin E, Katz PP, Blanc PD. The occupational burden of chronic obstructive pulmonary disease. Eur Respir J. 2003; 22: 462-469.

27. Burge PS. Occupation and chronic obstructive pulmonary disease (COPD). Eur Respir J. 1994; 7: 1032-1034.

28. Minov J, Karadzinska-Bislimovska J, Vasilevska K, RisteskaKuc S, Stoleski S. Exposure to environmental tobacco smoke in the workplace in Macedonia: Where are we now? Arh Hig Rada Toksikol. 2008; 59: 103-109.

29. Minov J, Karadzinska-Bislimovska J, Vasilevska K, Nelovska Z, Risteska-Kuc S, Stoleski S, Mijakoski D. Smoking among Macedonian workers five years after the anti-smoking campaign. Arh Hig Rada Toksikol. 2012; 63: 207-213.

30. Zuskin E, Neil Schachter E, Kanceljak B, Witek TJ. Immunological and respiratory reactions in workers exposed to organic dusts. Int Arch Occup Environ Health. 1994; 66: 317-324.

31. Mustajbegovic J, Zuskin E, Neil Schachter E, Kern J, Vitale K, Ebling Z, Vrcic-Keglevic M. Respiratory findings in chemical workers exposed to low concentrations of organic and inorganic air pollutants. Am J Ind Med. 2000; 38: 431-440.

32. Minov J, Karadzinska-Bislimovska J, Vasilevska K, RisteskaKuc S, Stoleski S. Exercise-induced bronchoconstriction in textile and agricultural workers and in bakers. Arh Hig Rada Toksikol. 2006; 57: 379-386.

33. Minov J, Karadzinska-Bislimovska J, Vasilevska K, RisteskaKuc S, Stoleski S. Bronchial hyperresponsiveness in workers exposed to organic dusts: effect of smoking. Allergy Hypersensitivity Asthma. 2006; 4 (1): 11-20

34. Dimich-Ward H, Kennedy S, Chan-Yeung M. Occupational exposures and chronic airflow limitation. Can Respir J. 1996; 133140.

35. Noertjojo HK, Dimich-Ward H, Peelen S, Dittrick M, Kennedy S, Chan-Yeung $M$. Western red cedar dust exposure and lung function loss: a dose-response relationship. Am J Respir Crit Care Med. 1996; 154: 968-973.

36. Mandryk J, Alwis KU, Hocking AD. Work-related symptoms and dose-response relationship for personal exposures and pulmonary function among woodworkers. Am J Ind Med. 1999; 35: 481-490.

37. Glindemeyer HW, Lefante JJ, Jones RN, Rando RJ, Weill H. Cotton dust and across-shift change FEV1 as predictors of annual change in FEV1. Am J Respir Crit Care Med. 1994; 149: 584-590.

38. Zuskin E, Ivankovic D, Schachter EN, Witek TJ jr. A ten year follow-up study of cotton textile workers. Am Rev Resp Dis. 1991; 143: 301-305.

39. Enarson DA, Vedal S, Chan-Yeung M. Rapid decline in FEV1 in grain handlers. Relation to level of exposure. Am Rev Respir Dis. 1985; 132: 814-817. 
40. Reynolds SJ, Donham KJ, Whitten P, Merchant JA, Burmeister LF, Poppendorf WJ. Longitudinal evaluation dose-response relationships for environmental exposures and pulmonary function in swine production workers. Am J Ind Med. 1996; 29: 33-40.

41. Glindmeyer HW, Lefante JJ, Jones RN, Rando RJ, Abdel Kader $\mathrm{HM}$, Weill $\mathrm{H}$. Exposure-related declines in the lung function of cotton textile workers. Relationship to current workplace standards. Am Rev Resp Dis. 1991; 144: 675-683.

42. Zock JP, Sunyer J, Kogevinas M, Kromhout H, Burney P, Antó JM. Occupation, chronic bronchitis, and lung function in young adults: an international study. Am J Respir Crit Care Med. 2001; 163: 1572-1577.

43. Mastrangelo G, Tartari M, Fedeti U, Faddia E, Saia B. Ascertaining the risk of chronic obstructive pulmonary disease in relation to occupation using a case-control design. Occupational Medicine. 2003; 53: 165-172. 